\title{
GAMBARAN TINGKAT PENGETAHUAN IBU NIFAS TENTANG NUTRISI MASA NIFAS DI WILAYAH PUSKESMAS RINGINARUM KABUPATEN KENDAL TAHUN 2013
}

\author{
Ana Sundari ${ }^{1}$, Titik Sapartinah ${ }^{2}$, Titi Mursiti ${ }^{3}$ \\ 1,2,3UPP Kampus Kendal Poltekkes Kemenkes Semarang \\ ABSTRAK
}

Masa Nifas dimulai setelah plasenta lahir berakhir ketika alat kandungan kembali seperti keadaan sebelum hamil. Kebutuhan gizi seimbang sangatlah penting bagi ibu pada masa nifasi. Berdasarkan studi pendahuluan pada Maret 2013 di wilayah Puskesmas Ringinarum terhadap $10 \mathrm{ibu}$ nifas terdapat 8 orang tidak tahu tentang nutrisi masa nifas dan terdapat 2 orang sudah mengetahuinya.Penelitian menggunakan jenis penelitian deskriptif dengan pendekatan survey populasi dalam penelitian ini yaitu seluruh ibu nifas (0-40 hari) berjumlah 52. Sampel yang digunakan adalah 52 responden dengan menggunakan teknik Total Sampling. Penelitian dilaksanakan di Wilayah Puskesmas Ringinarum Kabupaten Kendal dengan waktu penelitian bulan April sampai September 2013.Berdasarkan hasil penelitian dari 52 responden diperoleh bahwa responden pengetahuan baik sebanyak 35 orang $(67,3)$. Kesimpulannya adalah Sebagian besar responden pengetahuan ibu nifas tentang nutrisi pada masa nifas adalah baik sebanyak 35 responden (67,3\%). Saran untuk petugas kesehatan untuk bisa memberikan informasi tentang nutrisi pada ibu nifas agar ibu nifas tidak melakukan pantang makanan.

Kata Kunci : Pengetahuan, nifas,pantang makanan 


\section{PENDAHULUAN}

\section{A. Latar Belakang}

Indonesia salah satu negara yang sedang berkembang dengan berbagai jenis masalah dan hambatan dalam pembangunan kesehatan masyarakat. Salah satu hambatan yang sering terjadi dimasyarakat adalah adanya pantang makanan setelah melahirkan, padahal setelah melahirkan seorang wanita memerlukan nutrisi yang cukup

untuk memulihkan kembali seluruh alat genetalianya. Mereka tidak menyadari bahwa tindakannya berpengaruh terhadap pemulihan kesehatan kembali, juga terlambatnya pertumbuhan bayi (Kardinan,2008; h.1).

Angka kematian ibu maternal, karena kehamilan, persalinan dan masa nifas, mempunyai manfaat mencerminkan resiko yang dihadapi oleh ibu selama kehamilan dan melahirkan yang dipengaruhi oleh keadaan sosial ekonomi, keadaan kesehatan yang kurang baik menjelang kehamilan, kejadian berbagai komplikasi pada kehamilan dan kelahiran tersedianya dan penggunaan fasilitas pelayanan kesehatan termasuk pelayanan prenatal dan obstetri.

Masa Nifas [puerperium] dimulai setelah plasenta lahir dan berakhir ketika alat-alat kandungan kembali seperti keadaan sebelum hamil. Masa Nifas berlangsung selama kira-kira 6 minggu atau 42 hari,merupakan waktu yang Midwifery Care Journal diperlukan untuk pulihnya alat kandungan pada keadaan yang normal. Asuhan masa nifas diperlukan dalam periode ini karena merupakan masa kritis baik ibu maupun bayinya. Paling sedikit 4 kali kunjungan masa nifas dilakukan untuk menilai status ibu dan bayi baru lahir dan untuk mencegah, mendeteksi dan menangani masalah-masalah yang terjadi (Saifudin, Abdul Bari; 2006).

Di Puskesmas Ringinarum pada tahun 2012 jumlah kematian ibu sebesar 2 jiwa sedangkan pada tahun 2011 jumlah kematian ibu sebesar 3 jiwa, sedang ibu nifas sejumlah 610 orang dan terdapat 88 orang (14\%) yang mengalami masalah yang berkaitan dengan masa nifas diantaranya lbu nifas yang mengalami KEK.

Mengingat hal ini maka dalam masa nifas ibu harus melakukan perawatan khusus. Salah satu perawatan yang harus diperhatikan adalah pemenuhan nutrisi untuk pemulihan kesehatan disamping untuk memproduksi air susu ibu (ASI) dan membantu menjaga kesehatan bayi (Prawirohardjo, 2007; h. 356).

Kebutuhan gizi seimbang baik kualitas maupun kuantitasnya sangatlah penting bagi ibu pada masa nifas atau menyusui. Namun fenomena yang sering terjadi di masyarakat pedesaan adalah kuatnya pengaruh sosial budaya terhadap kebisaan sehari-hari. Adat dan tradisi merupakan dasar perilaku tersebut. Fenomena inilah 
yang masih mempengaruhi kebiasaan masyarakat Wilayah Puskesmas Ringinarum Kecamatan Ringinarum Kabupaten Kendal dalam hal memilih dan menyajikan makanan. Masyarakat masih mempercayai adanya pantang makanan, mereka menerima dan menolak jenis pangan tertentu.

Menurut masyarakat Jawa yang menjalani tradisi "pantang makanan" tindakan membatasi makan dan minum selama masa nifas, selama waktu itu ibu nifas tidak boleh makan seperti ikan, daging, buah terlalu banyak, karena dianggap akan memperlama proses pemulihan. Bahkan untuk minum pun di batasi hanya beberapa gelas tiap harinya. Sebenarnya kebutuhan gizi ibu nifas terutama jika menyusui akan meningkat $25 \%$, karena untuk proses pemulihan sehabis melahirkan dan untuk memproduksi ASI yang cukup untuk menyehatkan bayinya (Setyo dan Retno, 2011; h.125).

Masalah kematian maupun kesakitan pada ibu yang berhubungan dengan faktorfaktor sosial budaya dan lingkungan di dalam masyarkat dimana mereka berada. Faktor-faktor kepercayaan dan pengetahuan budaya seperti konsepsi mengenai berbagai pantangan, hubungan sebab akibat antara makanan dan kondisi sehat-sakit, kebiasaan serta ketidaktahuan, seringkali membawa dampak baik positif maupun negatif terhadap kesehatan ibu dan anak (Mass 2004).

Berdasarkan penelitian yang Baumali (2009) banyak masyarakat dari berbagai budaya percaya adanya hubungan antara pantang makanan dengan kesehatan ibu nifas yang sebenarnya salah, mereka memberikan perlindungan yang bersifat protektif terhadap ibu nifas sehingga keputusan untuk mengkonsumsi makanan ditentukan oleh pihak yang memiliki kewenangan, dalam hal ini suami atau orang tua atau dukun bayi.

Berdasarkan studi pendahuluan yang dilakukan di Wilayah Puskesmas Ringinarum didapatkan hasil bahwa dari 10 ibu nifas 8 orang tidak mengetahui tentang nutrisi masa nifas sedangkan 2 orang lainnya sudah mengetahuinya. Berdasarkan informasi dari bidan koordinator Puskesmas Ringinarum bahwa masyarakat di Wilayah Puskesmas Ringinarum masih menganjurkan ibu nifas untuk berperilaku pantang makanan.

Dari latar belakang diatas maka peneliti tertarik untuk melakukan penelitian tentang "Gambaran Tingkat Pengetahuan Ibu Nifas Tentang Nutrisi Masa Nifas Di Wilayah Puskesmas Ringinarum Kabupaten Kendal".

\section{B. Tujuan Penelitian}

Tujuan penelitian ini adalah untuk mengetahui pengetahuan ibu nifas tentang nutrisi masa nifas di wilayah Puskesmas Ringinarum Kabupaten Kendal.

\section{METODOLOGI PENELITIAN}


Jenis penelitian yang digunakan dalam penelitian ini menggunakan penelitian deskriptif yaitu mendeskripsikan seperangkat peristiwa atau kondisi populasi tersebut (Hidayat, 2010;h.53). Penelitian ini bertujuan untuk mengetahui pengetahuan ibu nifas tentang ASI Ekslusif. Penelitian ilmiah ini menggunakan variable tunggal yang berdiri sendiri, yaitu pengetahuan ibu nifas tentang nutrisi masa nifas.

Populasi adalah Keseluruhan objek penelitian atau objek yang diteliti (Notoatmodjo,2005; h.79). Populasi dalam penelitian ini adalah seluruh ibu nifas (0 40 hari) berjumlah 52 ibu nifas di Wilayah Puskesmas Ringinarum Kecamatan Ringinarum Kabupaten Kendal. Sampel merupakan bagian populasi.

Kriteria inklusi dalam penelitian ini adalah : lbu nifas yang ada di wilayah Kriteria ekslusi dalam penelitian ini tidak ada karena pantang makanan atau berpantang makanan yang dimaksud adalah makan dan minum apa saja yang dilakukan atau bukan karena penyakit sehingga seluruh ibu nifas dapat diteliti yaitu berjumlah 52 ibu nifasPuskesmas Ringinarum sebanyak $52 \mathrm{lbu}$ nifas yang bersedia. Tehnik sampling dalam penelitian ini menggunakan total sampling, yaitu teknik penentuan sampel dengan mengambil seluruh anggota populasi sebagai responden atau sampel (Sugiyono, 2010; h. 124).
Metode pengumpulan data yang digunakan dalam peneliti ini adalah menggunakan hasil pengisian lembar kuesioner. Teknik Pengambilan data dengan menggunakan data primer dan sekunder. Data primer menggunakan kuesioner. Data sekuder adalah data yang telah dikumpulkan oleh pihak lain dan data sudah ada. Dalam penelitian ini, data sekunder diambil dari laporan Bidan Desa, Puskesmas Ringinarum.

Menurut Notoatmodjo (2005), instrumen penelitian adalah suatu alat yang digunakan unuk pengumpulan data. Instrumen yang digunakan dalam penelitian ini adalah kuesioner. Mengingat intrumen ini belum baku, maka akan dilakukan Validitas oleh ahli (eksped) dalam hal ini kuesioner telah diusulkan dan disahkan oleh ahlinya.

Mengingat intrumen ini belum baku, maka akan dilakukan Validitas oleh ahli ( eksped ) dalam hal ini kuesioner telah diusulkan dan disahkan oleh ahlinya.

Metode penggolahan data dengan penyuntingan (Editing) editing yaitu kegiatan memeriksa data terkumpul, apakah sudah berisi secara sempurna atau tidak, cara pengisian sudah benar atau belum, pengkodean (Coding) Coding yaitu memberikan kode - kode tertentu kepada masing - masing kategori atau nilai dari setiap variabel yang dikumpulkan datanya, skoring setelah pemberian kode selesai kemudian dilakukan skoring sesuai kriteria yang dibuat peneliti. Dalam hal ini adalah 
pengetahuan. Kategori pengetahuan baik $\geq 76 \%$, pengetahuan cukup $56 \%-75 \%$, pengetahuan kurang $<56 \%$. Tabulasi (Tabulating) Tabulasi yaitu Membuat tabel jawaban-jawaban yang telah dikategorikan yang sebelumnya telah dimasukkan dalam tabel pemindahan

Analisis data dengan univariat yaitu analisis yang dilakukan terhadap tiap variable dari hasil peneltian dan mengjhasilkan distribusi dan prosentase dari tiap variable (Notoatmodjo,2005;h.186).

Analisa univariat dapat dihitung menggunakan rumus sebagai berikut:

$$
x=\frac{f}{n} \times 100 \%
$$

Keterangan :

$x \quad$ : Hasil persentase

f : Frekuensi hasil penelitian

n : Total seluruh observasi

Etika Penelitian menurut Aziz Alimul Hidayat (2007) etika dalalam penelitian ini adalah: Lembar persetujuan Penelitian (Informed Consent) Informed Consent merupakan bentuk persetujuan antara peneliti dengan responden penelitian dengan memberikan lembar persetujuan. Tanpa Nama (Anominity) Peneliti tidak memberikan atau mencantumkan nama responden pada lembar alat ukur dan hanya menuliskan kode pada lembar pengumpulan data atau hasil penelitian yang disajikan.Kerahasiaan (Confidentiality) Semua informasi yang telah dikumpulkan dijamin kerahasiaan nya oleh peneliti,hanya kelompok data tertentu yang akan dilaporkan pada hasil riset.

\section{HASIL DAN PEMBAHASAN}

\section{A. Hasil Penelitian}

Hasil penelitian tentang gambaran pengetahuan ibu nifas tentang nutrisi masa nifas di puskesmas ringinarum kabupaten kendal, menggunakan analisa univariat dapat dilihat pada tabel berikut :

Tabel $1.1 \quad$ Distribusi $\quad$ Frekuensi Pengetahuan Ibu Nifas Tentang Nutrisi Masa Nifas Di Puskesmas Ringinarum Kabupaten Kendal Tahun 2013

\begin{tabular}{lcr}
\hline Pengetahuan & Frekuensi & $\begin{array}{r}\text { Persentase } \\
(\%)\end{array}$ \\
\hline Baik & 35 & 67,3 \\
Cukup & 17 & 32,7 \\
\hline Total & 52 & 100,0
\end{tabular}

\section{B. Pembahasan}

Pada kenyataannya dilihat dari hasil penelitian terhadap 52 responden, 35 responden $(67,3 \%)$ ibu nifas sudah mengetahui tentang kebutuhan nutisi masa nifas dengan benar seperti konsumsi banyak makanan yang mengandung protein dan cukup cairan, tetapi masih banyak diatara mereka yang berpantang makan karena pengaruh budaya dan sikap masyarakat yang tidak modern dan menggunakan budaya lama nenek moyang. 
Ibu nifas yang termasuk dalam kategori pengetahuan cukup sebanyak 17 orang $(32,7)$ menyatakan tidak tau tentang kebutuhan ibu pada nifas dan cenderung mengikuti budaya dan adat didaerah yang melakukan pantangan terhadap beberapa makanan dan membatasi konsumsi cairan. Hal ini dapat berakibat buruk pada ibu, karena masa nifas merupakan masa pemulihan setelah bayi lahir sampai kembalinya organ-organ ke keadaan sebelum hamil.

Kebutuhan gizi seimbang baik kualitas maupun kuantitasnya sangatlah penting bagi ibu pada masa nifas atau menyusui. Namun fenomena yang sering terjadi di masyarakat pedesaan adalah kuatnya pengaruh sosial budaya terhadap kebisaan sehari-hari.

\section{PENUTUP}

\section{A. Simpulan}

Berdasarkan hasil penelitian tentang Gambaran Pengetahuan Ibu Nifas Tentang Nutrissi Masa Nifas di Wilayah Puskesmas Ringinarum Kabupaten Kendal dapat disimpulkan bahwa ibu hamil yang sudah memiliki pengetahuan baik sebanyak 35 responden $(67,3 \%)$ sedangkan pengetahuan cukup sebanyak 17 responden $(32,7 \%)$.

\section{B. Saran}

Saran dalam penelitian ini adalah diharapkan bagi tenaga kesehatan agar bisa memberikan informasi tentang nutrisi pada ibu nifas yang baik dan benar.

\section{DAFTAR PUSTAKA}

1. Anggraini,Yetti. Asuhan Kebidanan Masa Nifas, Yogyakarta : Pustaka Rihana; 2010,h.1,3,39.

2. Arikunto, Suharsimi. Prosedur Penelitian Suatu Pendekatan Praktik, Jakarta : Rineka Cipta; 2011.h. 194,211,221.

3. Dahlan, M.S. Statistic Untuk Kedokteran dan Kesehatan edisi 3. Jakarta : Salemba Medika ; 2008. h. 133

4. Dinas Kesehatan. Gizi Ibu Nifas (didapat dari http://dinkes.co.org.2006) diakses tanggal 13 Maret 2013.

5. Eny dan Diah. Ssuhan Kebidanan Nifas, Jogjakarta : Nuha Medika; 2010. h.97-103

6. Hidayat, Azizi Alimul. Metode enelitian Kebidanan dan Teknik Analisis Data, Jakarta: Salemba Medika; 2007. h.68.

7. ristiyanasari, Weni. ASI, Menyusui dan Sadari, Yogyakarta : Nuha Medika ; 2009. h.11

8. Mass L2004. Kesehatan Ibu dan Anak : Presepsi Budaya dan Dampak pada

Kesehatannya (http://library.usu.ac.id/download/ikm 
/km\%20linda.pdf) diakses pada tanggal 13 Mei 2013

9. Notoatmodjo, Soekidjo. Pendidikan dan Perilaku Kesehatan, Jakarta : Rineka Cipta; 2003. h.1220-124,170174.

10. Nursalam. Konsep dan Penerapan Metodiologi Penelitian IImu Perawatan. Jakarta ; 2008. h.101

11. Prawiroharjo, Sarwono.llmu Kebidanan. Jakarta : EGC; 2007. h.358

12. Profil Kesehatan Provinsi Jawa Tengah 2010

13. Sahela, Siti. Asuhan Kebidanan pada Masa Nifas, Jakarta : Salemba Medika; Press 2009. h.2,56,61

14. Setyo Handayani, Asuhan Kebidanan Ibu Masa Nifas, Yogyakarta : Gosyen publishing; 2011.h.125

15. Sugiyono, Statistik Untuk Penelitian, Bandung : Alfabeta; 2010.h.61

16. Suryoprajogo Nadine. Keajaiban Menyusui, Jogjakarta : 2009.h.10

17. Wawan A \& Dewi M. Teori Pengukuran Pengetahuan. Sikap dan Perilaku Manusia. Yogyakarta : Nuha Medika ; 2010.h.48-51

18. Wulandari,Setyo Retno dan Sri Handayani. Asuhan Kebidanan Ibu Masa Nifas. Jakarta:Gosyen :

Publising; 2011. h.125 